Chronologia (2021) vol. 3 no. 1 hal. 36-43

http://dx.doi.org/ 10.22236/jhe.v3i1.7193

E-ISSN: 2686-0171

\title{
Pengelolaan Pasar Jongkok di Tembilahan Tahun 2009-2015
}

\author{
Management of the Pasar Jongkok in Tembilahan 2009-2015 \\ Tari Okta Ayumi ${ }^{1 凶}$, Ahmal $^{2}$, Asril $^{3}$ \\ $1 \bowtie 23$ Universitas Riau \\ E-mail: tariokta44@gmail.com ${ }^{凶}$, ahmal.ur@gmail.com, asril.unri@gmail.com
}

Diterima: 28 Juni 2021 | Direvisi: 29 Juli 2021 | Diterbitkan: 29 Juli 2021

\section{ARTICLE INFO}

Keywords:

Management,

Pasar Jongkok

Tembilahan.

\author{
Kata Kunci: \\ Pengelolaan, \\ Pasar Jongkok, \\ Tembilahan.
}

\section{ABSTRACT}

This study aims to determine the Management of the Pasar Jongkok in Tembilahan 2009-2015 (management of the Jongkok market in Tembilahan). The existence of the Pasar Jongkok is an important element in the life of the Tembilahan community and is one of the drivers of the community and social economy. Pasar Jongkok was originally founded in 1936 but experienced a setback until the existence of this Pasar Jongkok began to reappear in the 1980s. This Pasar Jongkok has a social impact on the people of Tembilahan and is able to increase interaction between traders who sell in the Pasar Jongkok. This study uses qualitative research with a historical approach. Therefore, the researcher uses four stages consisting of: heuristics, source criticism, interpretation and historiography. In the heuristic stage, researchers use existing traders and management agencies as sources and make them primary sources. For secondary sources, researchers use books as the main source and are supported by journal articles. Furthermore, the researcher also applies source criticism and interpretation in order to obtain valid results from the various data obtained. Then the historiography was carried out. The results found in this study are the history of the Jongkok market in the city of Tembilahan, the management of the Jongkok market in the city of Tembilahan and the impact of the existence of the Pasar Jongkok in the city of Tembilahan.

Penelitian ini bertujuan untuk mengetahui Pengelolaan Pasar Jongkok di Tembilahan 2009-2015 (management of the pasar Jongkok in Tembilahan ). Keberadaan Pasar Jongkok menjadi salah satu elemen penting dalam kehidupan masyarakat Tembilahan dan menjadi salah satu penggerak roda perekonomian masyarakat dan sosial. Pasar Jongkok awalnya didirikan pada tahun 1936 namun mengalami kemunduran hingga keberadaan Pasar Jongkok ini mulai muncul kembali pada tahun 1980-an. Pasar Jongkok ini memberikan dampak sosial bagi masyarakat Tembilahan serta mampu meningkatkan interaksi antara pedagang yang berjualan di pasar jongkok tersebut. Penelitian ini menggunakan penelitian kualitatif dengan pendekatan sejarah. Maka dari itu peneliti menggunakan empat tahapan yang terdiri dari: heuristik, kritik sumber, interpretasi dan historiografi. Pada tahapan heuristik peneliti menggunakan pedagang serta dinas pengelola yang ada sebagai narasumber dan menjadikannya sumber primer. Untuk sumber sekunder, peneliti lebih memanfaatkan buku sebagai sumber utamanya dan didukung dengan artikel jurnal. Selanjutnya peneliti juga menerapkan kritik sumber serta interpretasi demi mendapatkan hasil yang valid dari berbagai data yang didapatkan. Kemudian baru dilakukan historiografi. Hasil yang ditemukan dalam penelitian ini berupa sejarah pasar Jongkok di kota Tembilahan, pengelolaan pasar Jongkok di kota Tembilahan serta dampak keberadaan pasar Jongkok di kota Tembilahan. 


\section{PENDAHULUAN}

Setiap daerah mempunyai tradisi dan kebudayaan yang membentuk karakter masyarakatnya. Indonesia adalah negara yang kaya dengan adat istiadat, tradisi dan budaya karena suku bangsa yang beragam salah satunya kegiatan jual beli di pasar tadisional ( $A$ \& Naredi, 2019) . Pasar adalah tempat fisik dimana pembeli dan penjual bertemu untuk mempertukarkan barang dan jasa (Kotler, 1997). sedangkan pasar menurut wujudnya dibedakan menjadi dua, yaitu pasar abstrak dan pasar kongkrit. Pasar abstrak lebih condong ke arah pasar online dimasa sekarang, dimana penjual dan pembelinya tidak bertemu langsung, sedangkan pasar konkret adalah pasar yang sering kita jumpai disekitar kita, dimana transaksi dapat dilihat secara nyata serta antara pedagang dan pembeli bertemu langsung. Di era saat ini pasar konkret mulai tersaingi keberadaannya dengan munculnya berbagai macam pasar abstrak serta mall-mall dengan pengelolaannya yang baik. Maka dari itu dalam permasalahan ini, pasar konkret akan dikaji lebih dalam khusunya pasar Jongkok.

Pasar Jongkok adalah pasar yang terdapat di Tembilahan, Kabupaten Indragiri Hilir, Provinsi Riau. Di pasar tersebut banyak sekali pedagang yang menjual barang bekas impor seperti pakaian,tas,alat elektronik, dan lainnya. Keberadaan ini mulai muncul sejak tahun 1980an dalam kemunculannya diawali dengan pedagang yang menggunakan kapal kayu yang membawa bahan makananan mentah seperti sayur-sayuran,pisang,ubi dan nenas yang mereka jual ke berbagai wilayah Riau perbatasan yaitu daerah Batam,Tanjung Balai Karimun bahkan sampai ke negara tetangga yaitu Singapura. Setelah barang mereka habis terjual merekapun membeli barang-barang bekas asal Singapura dibawa pulang dan dijual kembali kepada masyarakat. Hingga akhirnya barang bekaspun menumpuk di Kota Tembilahan. Masyarakat Indragiri Hilir menyebutnya dengan nama pasar jongkok karena ketika ingin membeli barang bekas tersebut pada saat memilih barangnya mereka harus berjongkok (Jumriati, 2019).

Pasar jongkok atau (PJ) ini diberi nama dengan nama pasar jongkok alasannya karena barang dagangannya dibentangkan di plastikplastik atau dikarung-karung lebar yang dibentangkan di emperan toko, atau dipinggirpinggir jalan, deretan-deretan toko. Jadi kalau ada yang mau melihat barang yang didagangkan, maka harus dengan berjongkok. para pedagang barang bekas dipasar jongkok ini berjualan dari sore hingga malam hari, rutin dilakukan setiap harinya. Perdagangan barang bekas di Tembilahan sudah berlangsung sejak lama, pedagang barang bekas ini mengalami pasang surut dalam perkembangannya karena memang harus bersaing dengan para pedagang barang baru yang yang jumlahnya sangat banyak sekali di Kota Tembilahan.

Setelah adanya Peraturan Kementerian Perdagangan jumlah pedagang di pasar jongkok mengalami penurunan namun dengan berkurangnya jumlah pedagang di pasar jongkok Tembilahan tidak membuat pasarpasar barang bekas yang ada di Tembilahan sepi pembeli. Masyarakat dari Tembilahan 
Ayumi, Ahmal \& Asril, 2021, Pengelolaan Pasar Jongkok ...

maupun dari luar Tembilahan masih ramai untuk membeli barang bekas, walaupun harga barang bekas itu lebih mahal dari sebelumnya. Pengelolaan pasar di wilayah Kabupaten Indragiri Hilir, diatur dalam Peraturan Daerah Kabupaten Indragiri Hilir Nomor 16 tahun 2009 tentang Pengelolaan pasar desa,dimana Peraturan Daerah tersebut dibentuk dalam rangka mendukung penyelenggaraan otonomi desa dan menciptakan perekonomian desa yang kuat dan mandiri serta mengembangkan potensi pasar desa sebagai sumber daya ekonomi desa. Bedasarkan paparan diatas, penulis tertarik untuk meneliti dan memahami bagaimana pengelolaan pasar jongkok di Tembilahn dari masa ke masa, serta menuangkannya dengan judul "Pengelolaan Pasar Jongkok di Tembilahan 2009-2015".

\section{METODE}

Tipe penelitian ini menggunakan penelitian sejarah dengan pendekatan kualitatif. Menurut Edson metode sejarah adalah menggambarkan permasalahan atau pertanyaan untuk diselidiki, mencari sumber fakta historis, meringkas dan mengevaluasi sumber-sumber historis dan menyajikan fakta-fakta yang bersangkutan dalam satu kerangka interaktif (Dadang, 2007). Maka dari itu metode sejarah dapat dikatakan sebagai seperangkat aturan prinsip sistematis untuk mengumpulkan sumber-sumber sejarah secara efektif, menilainya secara kritis dan mengajukan sintesis dari hasil-hasil yang telah dicapai dalam bentuk tertulis(Gunawan et al., 2020). Metode sejarah sendiri memiliki empat tahapan yakni, heuristik, kritik sumber, interpretasi, dan historiografi (Dudung, 2007).
Pada tahap heuristik, peneliti menggunakan pedagang pasar jongkok dan pegawai Dinas Perdagangan dan Perindustrian Kabupaten Indragiri Hilir, sebagai sumber primer. Untuk sumber sekunder menggunakan buku-buku serta jurnal yang dianggap tepat. Setelah berbagai sumber didapatkan, maka tahapan selanjutnya yakni analisis data dengan melakukan kritik terhadap berbagai data yang telah didapatkan serta didukung dengan interpretasi. Jika hasil sudah jenuh maka dilakukan penarikan kesimpulan dan penulisan atau dalam ranah sejarah dikenal sebagai historiografi (Hari Naredi, 2020).

\section{HASIL DAN PEMBAHASAN}

\section{AWAL PASAR JONGKOK DI KOTA TEMBILAHAN}

Pasar Jongkok di bangun pada masa kolonial Belanda pada tahun 1936. Dahulunya daerah ini merupakan daerah yang sangat padat pemukimannya. Untuk menunjang sektor perekonomian tersebut, maka di daerah ini dahulunya juga terdapat pelabuhan bea dan cukai, serta dermaga. "Jika melihat sejarahnya, masyarakat Tembilahan telahmengeluti usaha berjualan sepatu bekas sejak tahun 1980-an. Siapa saja yang pernah berkunjung ke Tembilahan, tentu tidak asing mendengar kata PJ. Secara etimologi tidak diketahui kapan kata PJ ini mulai digunakan oleh masyarakat Tembilahan sebagai kata lain untukmenyebut pasar sepatu bekas. Masyarakat Indragiri Hilir pada umumnya dan masyarakat Tembilahan pada Khususnya sangat mengenal PJ diketahui merupakan akronim atau singkatan dari kata "pajak". 
Pada perkembangan berikutnya ada yang mengartikan PJ sebagai "Pasar Jongkok" . Istilah PJ sebagai pasar jongkok mulai popular sekitar tahun 2000-an, para pedagang mulai menggelar dagangan pada malam hari $d$ sepanjang trotoar dan alun-alun Tembilah. Para pengunjung yang ingin membeli biasanya harus berjongkok untuk melihat-lihat barang dagangan dan berinteraksi dengan para pedagang. Dari sinilah mungkin muncul arti lain PJ sebagai pasar jongkok. Istilah PJ juga sudah lama dipergunakan oleh masyarakat kota medan. Sematera Utara. Bedanya kalau di kota Medan, PJ berarti pajak, sebutan lain untuk pasar pada umumnya, sedangkan di Tembilahan PJ berarti yang khususnya menjual aneka barang bekas.

Pasar Jongkok ini terletak di jalan Sultan Syarif Kasim, dimana barang-barang yang akan di jual tepatnya terletak di depan toko-toko yang tidak lagi beraktifitas setelah magrib.Pedagang menyajikan dagangannya beralaskan terpal atau karung dan ada juga yang tidak beralaskan sama sekali. Pasar ini dapat di jumpai pada saat malam hari dengan penerangan lampu yang sederhana yang di pasang dibawah terpal biru. Sarana ini digunakan untuk melindungi barang dagangan saat hujan turun. Pada areal sekeliling pasar jongkok ini terdapat bangunanbangunan ruko (rumah toko) baik bangunan lama atau bangunan baru potensi komersial dan rekreasi merupakan faktor penting sebagai upaya perwujudan ekonomi masa depan bagi perekonomian rakyat (Gunawan \& Rozi, 2020). Pasar Jongkok adalah jenis pasar yang berisi lapak orang yang ingin menjual atau barter berbagai barang mulai barang berkualitas rendah sampai barang berkualitas tinggi. Pasar Jongkok ini adalah pasar yang menjual barang bekas dari luar negeri mulai dari barang pecah belah dari china, pakaian dalam pria dan wanita, aksesoris rumah tangga, pakaian dari Malaysia dan Singapura, sepatu dengan berbagai macam merek seperti: nike, vans, dan tas juga da[pat di jumpai berbagai macam merek ternama seprti gucci dan lainnya, berbagai macam permainan anakanak, barang-barang elektronik, dan lainnya. Pasar ini buka dari pukul 16.00-2300 WIB. Pasar ini diberi nama pasar jongkok karena barang dagangannya dibentangkan di plastikplastik atau di karung-karung lebar yang dibentangkan di emperan toko, atau di pinggirpinggir jalan, di antara deretan-deretan toko. Jadi, kalau ada yang mau melihat barang yang di dagangkan, maka harus dengan berjongkok.

\section{PENGELOLAAN PASAR JONGKOK DI KOTA TEMBILAHAN}

Pasar Jongkok di Tembilahan dikelolah oleh Asosiasi Pedagang Kaki Lima (APKL). Asosiasi Pedagang Kaki Lima (APKL) Pasar Jongkok diketuai oleh bapak Alex Saputra dan sekretaris dijabat oleh bapak $M$. Zainuddin. Kantor atau Sekretariat APKL Pasar jongkok terletak di jln $\mathrm{H}$. Khalidi No.25 Tembilahan. Dimana lokasi sekretariat APKL tersebut terletak tidak jauh dari wilayah pasar jongkok kota Tembilahan. APKL mulai beraktivitas dijalan Sultan Syarif Qasim, jalan Khalidi, dan jalan Guru sejak tahun 2005. Ini merupakan kebijakan pemerintah yang terdahulu, adapun lokasi ini merupakan pemindahan anggota APKL dari lapangan upacara Gajah Mada yang pada saat itu, 
Ayumi, Ahmal \& Asril, 2021, Pengelolaan Pasar Jongkok ...

lapangan digunakan pemerintah daerah untuk pelaksanaan MTQ tingkat Provinsi Riau, yang mana Tembilahan merupakan sebagai tuan rumah. Dan sesuai dengan kebijakan oleh pemerintah saat itu bahwa lokasi jalan Sultan Syarif Qasim, jalan Khalidi, dan jalan Guru Hasan ini sudah menjadi event wisata malam belanja di Kabupaten Indragiri Hilir.

Keberadaan Asosiasi Pedagang Kaki Lima atau (APKL) sebagai manifestasi penting dari modal sosial tidak mendapatkan prioritas lokasi di Jalan Sultan Syarif Qasim, Jalan Khalidi, dan Jalan Guru Hasan. Asosiasi Pedagang Kaki Lima ini muncul karena adanya "driving force" tertentu misalnya ketidakpuasan pedagang terhadap kebijakan pengelola lahan parkir atau pemerintah kota secara umum. Pada dasarnya peran dari Asosiasi Pedagang Kaki Lima tersebut antara lain adalah sebagai berikut:

a) Menampung aspirasi pedagang dan melakukan advokasi ke pihak pengelola parkir atau pemerintah kota

b) Memfasilitasi berbagai konflik yang terjadi di level pedagang atau pasar

c) Menjembatani pedagang dengan pengelola parkir

d) Melakukan pengawasan terhadap kinerja pengelolah

e) Memperjuangkan konsep pasar yang sesuai dengan kebutuhan pedagang

Pedagang pasar jongkok berjualan di tiga tempat, yang pertama pedagang berjualan di Jalan Guru Hasan, yang kedua di Jalan Sultan Syarif Qasim dan terakhir berjualan di Jalan Yos Sudarso. Pedagang yang berjualan di jalan Guru Hasan berjumlah sekitar 48 orang, yang berjualan di jalan Sultan Sarif Qasim berjumlah 100 orang dan yang berjualan di jalan
Yosudarso berjumlah 52 orang. Sedangkan untuk pemasok barang sendiri, rata-rata pedangan di pasar Jongkok memanfaatkan impor barang bekas yang dapat masuk ke Indonesia melalui beberapa jalur wilayah, yaitu:

1. Malaysia (Port Klang, Kuantan, Johor) ke Pantai Timur Sumatera (Pangkalan Brandan, Pematang Siantar, Dumai)

2. Malaysia (Tawao) ke Wanci, Palu, Makassar.

3. Singapura ke Batam, Pesisir Timur Sumatera, Pulau Wanci, Dili.

4. Timor Leste (Dili) ke Kupang, Maumere, Pulau Wangiwangi (Wanci).

5. Pulau Wangiwangi (Wanci) di Wakatobi ke Kendari, Makassar

6. Makasar ke Ambon, Bitung, Ternate, Poso, Manado, Surabaya

Dari semua jalur wilayah masuknya barang impor bekas ke Indonesia masuk melalui bagian Timur Pesisir Indonesia. Penyebab masuknya barang bekas impor tersebut ke Indonesia adalah karena banyaknya pelabuhan tikus. Pelabuhan tikus paling banyak ada di Pulau Sumatera bagian Timur yaitu 130 pelabuhan, dan 30 pelabuhan di Batam. Selain itu, data Kementerian Perdagangan menyebut Provinsi Riau menjadi pusat masuknya pakaian, sepatu, dan barang bekas lainnya ke Indonesia. Wilayah penampung barang bekas paling banyak adalah Tembilahan. Tembilahan merupakan ibu kota dari Kabupaten Indragiri Hilir di bagian Timur Provinsi Riau atau pada bagian Timur Pesisir Sumatera yang dikepung oleh air. Untuk menempuh perjalanan ke negara tetangga seperti Singapura hanya dibutuhkan 6 jam perjalanan dengan menggunakan speed boat. Dengan geografis seperti ini, sangat memudahkan bagi warga Tembilahan untuk 
melakukan kontak dagang dengan warga negara Singapura. Hal inilah salah satu faktor yang menjadi penyebab barang impor membanjiri kota Tembilahan.

Jika sebelumnya dibahas pengelolaan pasar Jongkok oleh dinas perdagangan, maka selanjutnya yakni pengelolaan pasar jongkok oleh dinas perdagangan. Pengelolaan Pasar Jongkok di Kota Tembilahan dari tahun 2009 sampai tahun 2015 yang dilakukan oleh Dinas Perdagangan dan Perindustrian Kabupaten Indragiri, hanya melakukan tugas pengawasan yang dilakukan oleh pegawai Dinas Perdagangan dan Perindustrian khususnya bidang pasar yaitu dilakukan pengawasan oleh pegawai sesuai dengan arahan dari Kepala Bidang Pasar. Sehingga membuat pengawasan yang dilakukan kurang efektif dan berjalan lambat dan tidak adanya aturan baku mengenai peraturan atau pengawasan Pasar Jongkok di kota Tembilahan. sedangkan pada tahun 2016, Dinas Perdagangan dan Perindustrian khususnya bidang pasar dalam melakukan pengawasan terhadap Pasar Jongkok di kota Tembilahan mengalami peningkatan yang cukup maksimal dengan dikeluarkan Surat Keputusan Bupati Kabupaten Indragiri Hilir mengenai lokasi berjualan bagi pedagang Pasar Jongkok terletak di tiga ruas jalan yaitu jalan Hasan Guru, jalan KH.Khalidi dan jalan Sultan Syarif Qasim.

\section{DAMPAK KEBERADAN PASAR JONGKOK DI TEMBILAHAN}

\section{Tanggapan Masyarakat terhadap Pasar Jongkok}

Pasar Jongkok Tembilahan, dari namanya sudah terlintas pemikiran yang negatif, pasar ini memang menyediakan barang-barang bekas dan barang-barang yang tidak jelas kelengkapannya, Pasar gelap (Black Market) yaitu suatu pasar dimana barang - barang dijual di atas harga maksimum yang ditetapkan secara resmi. Suatu tindakan dikategorikan sebagai ilegal apabila dianggap bertujuan mengurangi persaingan.

Etika pada dasarnya mempelajari perilaku atau tindakan seseorang dan kelompok atau lembaga yang dianggap baik atau tidak baik. Ukuran untuk menilai baik dan tidaknya suatu tindakan bila dilihat dari hakikat manusia utuh adalah dilihat dari manfaat atau kerugiannya bagi orang lain, kemampuan tindakan tersebut dalam menciptakan kebahagiaan individu dan kemampuan tindakan tersebut dalam meningkatkan keimanan atau kesadaran spiritual seseorang (Cenik, 2009).

Dengan adanya pasar ilegal, masyarakat Indonesia menanggapinya dengan positif dan ada juga yang menanggapi negatif dan bahkan ada juga masyarakat yang tidak peduli atau tidak mau ambil pusing. Pasar ilegal memang sudah ada sejak lama beredar di Indonesia, kini pasar ilegal di mata masyarakat tidak asing lagi, ada beberapa alasan kenapa konsumen memilih pasar illegal salah satunya di karenakan nilai harga jualnya yang lebih murah ketimbang di pasaran. Selain murah, pasar ilegal juga sangat menguntungkan bagi si pembeli. Ada beberapa keuntungan-keuntungan dari pasar ilegal bagi masyarakat, salah satunya yaitu : masyarakat bisa mendapatkan barang atau produk yang lebih murah dari harga pasaran (terutama bagi masyarakat menengah ke bawah), masyarakat juga menambah wawasannya terhadap 
Ayumi, Ahmal \& Asril, 2021, Pengelolaan Pasar Jongkok ...

ilegalitas dan legalitas dan dapat membedakan atau membandingkan mana yang legal dan mana yang ilegal sehingga mewujudkan kesadaran dari masyarakat dan itulah keuntungan yang paling terpenting Selain itu masyarakat dalam menanggapi adanya Pasar Jongkok yaitu banyak orang yang memilih berbelanja di Pasar Jongkok terutama dalam membeli pakaian atau sepatu, akan tetapi harus pintar - pintar dalam memilih barang karena tidak semua barang yang di jual kualitasnya bagus. Harga barang yang dijual di Pasar Jongkok ini juga relatif murah sehingga banyak orang yang memilih berbelanja di Pasar Jongkok Tembilahan.

\section{Dampak Pasar Jongkok terhadap Kehidupan Ekonomi Masyarakat}

Dengan adanya pasar jongkok di Tembilahan sangat membantu bagi masyarakat menengah ke bawah dalam memenuhi kebutuhan seharihari. Terkhusus bagi pedagang pasar jongkok dengan adanya pasar jongkok membantu mereka dalam memenuhi kebutuhan hidup mereka. Bagi pedagang pasar jongkok berjualan di pasar jongkok selain untuk memenuhi kebutuhan hidup mereka juga merupakan pekerjaan utama disebabkan karena mereka tidak memiliki pekerjaan yang lain atau yang sesuai selain berjualan di pasar jongkok. "Bagi pedagang pasar jongkok berjualan di pasar jongkok, pendapatan mereka lumayan lebih banyak dibandingkan dengan orang yang berjualan di toko-toko sehari-hari selain pendapatan yang mereka dapatkan lebih banyak, mereka bekerja dengan santai tidak terlalu memakan waktu yang banyak tidak sama dengan pekerjaan lain yang menggunakan waktu yang lama".(Yusro)
Bagi masyarakat yang tinggal disekitar pasar jongkok dengan adanya pasar jongkok dampaknya bagi mereka yaitu mereka yang tidak memiliki pekerjaan bisa bekerja menjadi juru parkir pasar jongkok. Dengan adanya pasar jongkok tidak hanya dapat meningkatkan kehidupan ekonomi masyarakat baik yang tinggal disekitar pasar jongkok maupun pedagang yang berjualan dipasar jongkok. Bagi pemerintah daerah pasar jongkok sudah ditetapkan menjadi wisata malam di Tembilahan dan pemerintah daerah juga menjadikan pasar Sebagai pendapatan asli daerah (PAD) oleh pemerintah Kabupaten Indragiri Hilir.

\section{KESIMPULAN}

Berdasarkan uraian di atas dapat disimpulkan bahwa Pasar Jongok Tembilahan merupakan pasar yang mempunyai peranan penting dalam dunia ekonomi dan dalam kehidupan sosial masyarakat, khususnya Kelurahan Tembilahan Kota, Kecamatan Tembilahan, Kabupaten Indragiri Hilir, Riau. Sekaligus berhasil menunjukkan keberadaannya dengan bukti mampu bertahan sampai sekarang. Berdasarkan penelitian dan pembahasannya, maka penulis dapat menarik suatu kesimpulan beberapa hal sebagai berikut : Pasar Jongkok didirikan untuk menampung pedagang yang dahulunya berjualan di lapangan gajah mada, dikeranakan lapangan tersebut digunakan oleh pemerintah daerah untuk lokasi mtq tembilahan, para pedagang tersebut dipindahkan berjualan di pasar jongkok di jalan Sultan Syarif Qasim supaya mereka bisa berjualan kembali dan untuk memenuhi kehidupan mereka sehari-hari, Pasar Jongkok di Tembilahan mengalami perkembangan yang cukup maksimal sehingga mampu bertahan 
sampai masa sekarang. Pasar Jongkok yang ada di Tembilahan sekarang ini terbagi menjadi 4 pasar yaitu: pasar dayung suri, pasar kayu jati, pasar pagi dan pasar jongkok, Masyarakat sangat senang dengan adanya pasar jongkok ini, karena dengan adanya pasar jongkok ini masyarakat terbantu dalam memenuhi kebutuhan hidupnya terutama bagi masyarakat menengah ke bawah, selain membantu masyarakat menengah kebawah dalam memenuhi kebutuhan hidupnya dengan adanya pasar jongkok ini juga membantu masyarakat sekitar pasar dalam meningkatkan kehidupan ekonomi mereka.

\section{DAFTAR PUSTAKA}

A, M. Y. A., \& Naredi, H. (2019). Perubahan Sosial Masyarakat Kuningan Melalui Budaya. 1, 664-673.

Cenik, S. A. (2009). Etika Bisnis dan Profesi. Jakarta: Salemba.

Dadang, S. (2007). Pendekatan IImu Sosial Sebuah Kajian Pendekatan,Struktural. Jakarta: Bumi Aksara.

Dudung, A. (2007). Metodologi Penelitian Sejarah. Yogyakarta: Ar-Ruzza Media Group.

Gunawan, R., \& Rozi, A. F. (2020). Utilization And Development Of Historical Sites For Improving The Economy Of The Region. 6(2), 82-89.

Gunawan, R., Utami, N., Rizki, A., Azzahra, H. F., Gunawan, R., Utami, N., Rizki, A., \& Azzahra, H. F. (2020). Research Article The Role Of Cultural Reservation Center ( Bpcb ) Jambi In Preserving History Site: Situs Bukit Siguntang. 4(1), 1-8.

Hari Naredi, A. (2020). Pengasingan Soekarno Tahun 1938-1942 Di Bengkulu. Jurnal Kajian, Penelitian \& Pengembangan Pendidikan Sejarah, 5(2), 94-101.

Hakim, M. A. (2005). Menguasai Pasar Menggeruk Untung. Jakarta: PT.Krisna Persada.
Jumriati. (2019). Eksistensi Pedagang Barang Bekas Impor di Tembilahan,Kabupaten Indragiri Hilir, Provinsi Riau. Jurnal Sosiologi, 2-3.

Kansil, C. S. (2000). Kitab Undang-undang Hukum Perusahaan. Jakarta: Pradya Pramita.

Kotler, P. (1997). Dasar-dasar Pemasaran. Jakarta: Pernhalindo.

Kotler, P. (2005). Manajemen Pemasaran. Jakarta: PT.Intan Sejati Klaten.

Todaro, M. P. (2000). Pembangunan Ekonomi. Jakarta: PT.Bumi Aksara. 